\title{
Seed bank of seasonally flooded grassland: experimental simulation of flood and post-flood
}

\author{
Francielli Bao $[$ - Tracy Elsey-Quirk • Marco Antonio de Assis • Arnildo Pott
}

Received: 7 June 2017/Accepted: 13 November 2017/Published online: 20 November 2017

(C) Springer Science+Business Media B.V., part of Springer Nature 2017

\begin{abstract}
Wetland seed banks comprise the propagules of plant species that have species-specific germination requirements for germination in either flooded or dry conditions. At the community level, wetland structure and succession during and after a seasonal flooding event depends upon the early lifehistory requirements of species, including germination under flooded and dry conditions. We examined the effects of simulated flood and post-flood scenarios on seedling emergence from a seed bank of seasonally
\end{abstract}

Handling Editor: Kevin Murphy.

Electronic supplementary material The online version of this article (https://doi.org/10.1007/s10452-017-9647-y) contains supplementary material, which is available to authorized users.

F. Bao $(\bowtie) \cdot$ M. A. de Assis

Instituto de Biociências, Universidade Estadual Paulista

(UNESP), Campus de Rio Claro, Rio Claro,

SP 13506-900, Brazil

e-mail: franbao@yahoo.com.br

M. A. de Assis

e-mail: massis@rc.unesp.br

T. Elsey-Quirk

Department of Oceanography and Coastal Sciences,

Louisiana State University (LSU), Baton Rouge,

LA 70803, USA

e-mail: tquirk@1su.edu flooded grassland in the Pantanal, Brazil. Field samplings were conducted in both wet and dry seasons, both of which were subject to flood and post-flood conditions. A total of 70 species emerged from the seed bank, dominated by Poaceae and Cyperaceae. Sixteen species were exclusive to the wet and one exclusive to the dry season. The richness of perennial species was higher under flood conditions, while the richness of annuals was greater postflood. In general, the aquatic and amphibious species exhibited a significant germination response to flooding. Terrestrial species only germinated in post-flood conditions, with higher richness in the dry season. Four species had high seedling abundance in both treatments. The capacity of regeneration by seeds is high in these grasslands and can be increased by
A. Pott
PPG Biologia Vegetal, Universidade Federal de Mato Grosso do Sul, Campo Grande, MS 79070-900, Brazil e-mail: arnildo.pott@gmail.com 
seasonal flooding and drawdown. In these seasonally flooded grasslands, we observed three main germination strategies: under flooded conditions, aquatic and amphibious species; post-flood conditions, an explosion of annual amphibious and terrestrial species; and in moist soil, perennial terrestrial species. The differential responses to flooding versus post-flood conditions help to maintain the structure and species richness in the community over time.

Keywords Growth forms $\cdot$ Life cycle $\cdot$ Seasonal flooding $\cdot$ Seedling $\cdot$ Wetland

\section{Introduction}

Seasonally flooded wetlands can harbor a mixture of plant species tolerant of flooded and/or dry conditions (Grime 1977). Germination strategies are often cued to changes in soil moisture such that a different suite of species germinates in flooded versus dry conditions (Baskin and Baskin 2014). Across time, the richness and diversity of plant communities in seasonally flooded wetlands are dependent on both flooding and drawdown to allow the conditions necessary for germination and growth of individual species (Bonis et al. 1995; Pott and Pott 2004; Pott et al. 2011).

During flood periods, aquatic species may dominate, while during dry seasons, more terrestrial species may prevail. During each of the seasonal conditions, a group of species (aquatic/terrestrial) will be regenerating (Nielsen et al. 2002), that is, in seasonal wetlands the germination of many species varies according to the amount of water present in the soil (Brock 2011). Seasonal wetlands dominated by herbaceous species present an ideal system for examining regeneration strategies, due to the existence of two stable but alternating annual seasons (Ames et al. 2015) and rapid colonization of annual species (Barton et al. 2016), giving an answer in a short time.

The replacement of species in floodable grasslands can be limited by the availability of seeds (or other propagules) and/or of seedling establishment. Seed limitation occurs when not all seeds reach available sites for germination (Hubbell and Foster 1986). This can be due to the number of seeds (in higher numberannual plants; fewer-perennials) and/or limited seed dispersal (Schneider 1994; Dalling et al. 1998). In flood periods, corridors are formed that carry seeds for potentially long distances (Middleton 2003). Seeds can be trapped in the soil in different densities according to the topographic gradient (Pagotto et al. 2011; Bao et al. 2014). This environment can limit species richness and abundance in the community (Muller-Landau et al. 2002). Yet the limitation of establishment occurs when not all seeds germinate. Such limitation will depend on germination itself, with a direct influence by environmental factors including moisture, light, temperature (Long et al. 2015) and effect of seasonality (Hölzel and Otte 2001).

The germination response to seasonal events varies according to the duration and intensity of the flood, determining the occurrence or not of different groups of species (aquatic, amphibian and terrestrial); this is a fundamental mechanism for the structuring and composition of a plant community (Jutila 2001). The Brazilian Pantanal is marked by predictable annual floods (Pott and Silva 2015), where grasslands are flooded approximately 3-5 months per year. The magnitude of flooding, however, varies with topography and annual rainfall (the latter influenced, for example, by El Niño events) (Junk 1993; Pott and Pott 2004). Flooding of the grassland stimulates germination of aquatic macrophytes (Oliveira et al. 2015; Souza et al. 2016), while the seeds of terrestrial plants adapted to drier conditions remain in the seed bank waiting for the ideal conditions for colonization (Bao et al. 2014). The evaluation of the seed bank of wetlands can provide us with information on the different plant life-forms involved in the regeneration of this plant community under different environmental conditions, in order to identify which plant species can establish during and after a seasonal flood event (LaDeua e Ellison 1999; LePage et al. 2000; Brock 2011), and the species available for regeneration. These are important data to help inform understanding of factors influencing the continued survival of wetland plant communities, and to aid design strategies for their conservation (Thompson et al. 1997). Our study also provides new information on how differing species germination strategies, and variation in seed flood tolerance, may influence plant community succession in seasonally flooded tropical wetlands.

Our objectives were to evaluate the seed bank of floodable grasslands and to investigate how the lifeforms of the communities of species present in these 
dynamic systems respond to seasonal floods. We carried out experiments to simulate the effect of flood and post-flood conditions on the seed bank to examine changes in emergence from the seed bank. Specifically, we examined: (1) species primarily involved in initial regeneration during and after flooded and dry conditions; (2) life-history regenerative strategies in the seed bank in relation to seasonal variation (cycle of annual and perennial species); and (3) the established species in the grassland during flood and post-flood conditions (contrasting the occurrence of aquatic, amphibious, and terrestrial species).

\section{Methods}

\section{Region of study}

The Brazilian Pantanal wetland is the largest continuous floodplain on Earth, covering 140,000 $\mathrm{km}^{2}$, in Central-West Brazil, predominantly occupied by seasonally flooded grasslands and savannas. Flooding in the Pantanal is annual and predictable (Pott and Silva 2015) due to local rains and/or river overflow (Pott and Pott 2004). Topographic variation combined with local hydrologic regimes forms permanently and periodically flooded zones (Pott and Silva 2015). The climate is tropical sub-humid, with an average annual rainfall of $1100 \mathrm{~mm}$ and mean annual temperature of $26{ }^{\circ} \mathrm{C}$ (Allem and Valls 1987; Silva and Abdon 1998). The soil is sandy. The study area in Central-West Brazil (Fig. 1a), covering 9200 ha, is a seasonally flooded plain with natural grasslands and temporary water bodies containing aquatic macrophytes and, in the dry areas, numerous grasses and terrestrial herbs (Pott and Pott 2004).

The study area is utilized as pasture, mostly comprised of native grasses, but approximately $20 \%$ of it was cultivated with the exotic Urochloa humidicola (Rendle) Morrone \& Zuloaga. Flooding occurs between April and August with maximum water levels approximately $4 \mathrm{~m}$ above baseline datum (a.b.d.) in the nearby Miranda River in June-July and minimum water levels of $2 \mathrm{~m}$ (a.b.d) typically between October and December level (data collected at ranch Fazenda São Bento, between 2013 and 2015, Fig. 1b). Therefore, the floodplain undergoes predictable seasonal cycles of flooding and drawdown.
Seed bank collection

To evaluate the effect of seasonal flooding on seed bank composition, we sampled three elevation levels of eight temporary ponds during two periods characteristic of the Pantanal: the end of the wet season in July and August (2014 and 2015), and after the dry season in October and November (2013 and 2014). Ponds were selected with similar depths and areas. At each pond, three 10-m-long transects were established along a topographic gradient. Topographic levels (e.g., low, mid and high) with approximately $30-\mathrm{cm}$ vertical difference were established according to a reference of the flood-level water mark on fence poles and plants (Fig. 1c). Low topographic level was in the middle of the pond, the mid level was on the pond edge and the high level was on less flooded, higher ground. Stratifying by topographic level allowed us to sample the major habitat types, which may be structuring the seed bank and plant community in this system (e.g., Bao et al. 2014, 2015), during different densities of seeds captured at each level, due to the lowering of the waters after the seasonal flood (Pagotto et al. 2011; Bao et al. 2014). At low topographic levels, there is a higher seed density and a higher concentration of seeds of aquatic macrophytes. At the mid and high levels, the number of seeds of grasses and seeds of terrestrial grass increases (Bao et al. 2014).

Five soil samples were collected randomly along each transect according to a table of random numbers. The upper $3 \mathrm{~cm}$ depth of soil sample was collected within $20 \times 20 \mathrm{~cm}$ quadrats. Soil samples were kept in dark plastic bags, under ambient temperature, and transported to Universidade Federal de Mato Grosso do Sul (UFMS), immediately for germination studies.

Seed bank experiments

Soil samples were spread in plastic trays $(20 \times 20 \times 10 \mathrm{~cm})$ and then subject to a two-phase flooding regime simulating a 3 -month flood followed by a 3 -month drawdown. Specifically, samples were first submerged in tanks under $90 \mathrm{~cm}$ of water (flood treatment) for 3 months; the flood in tanks was similar to the depth observed in the field. Any filamentous algae growth was removed. Seedlings of aquatic plants were removed and placed into trays with bare soil in the greenhouse (post-flood treatment). Here, they were exposed to ambient air temperature and twice a day 


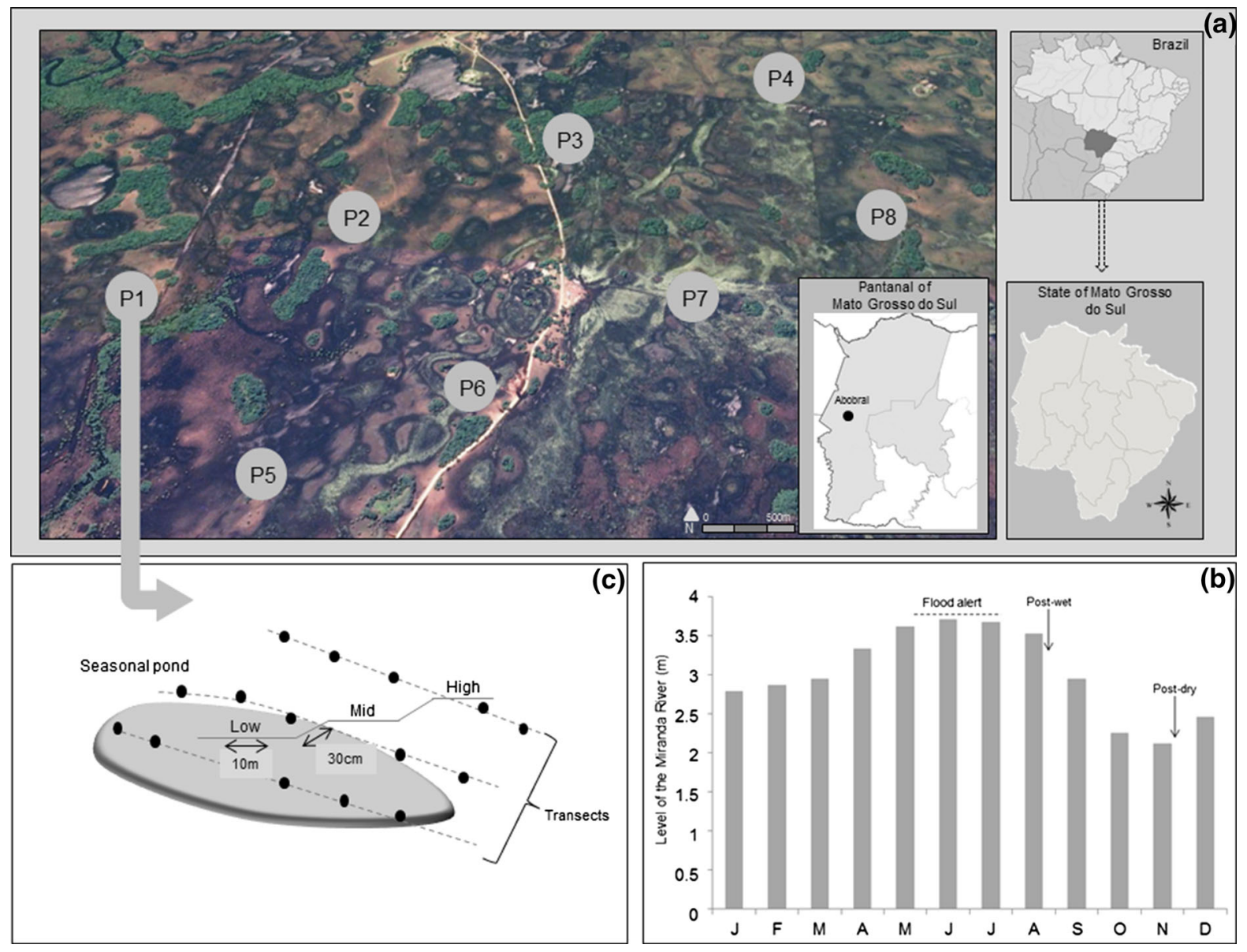

Fig. 1 Seasonally flooded grassland in the Pantanal wetland (Central-West Brazil). a Sampling points including eight seasonal ponds (P1-P8 in grassland-Image Source: "Fazenda São Bento," south Pantanal, $\left(19^{\circ} 29^{\prime} 27.3^{\prime \prime} \mathrm{S} ; 57^{\circ} 01^{\prime} 55.9^{\prime \prime} \mathrm{W}\right)$ Google Earth (accessed March 15, 2017)), b mean monthly level

watering for 3 months. Samples were randomly placed within the greenhouse and were moved around monthly to provide further randomization of light conditions (e.g., Bao et al. 2014).

The seed bank was evaluated using the seedling emergence method, whereby germinated seeds were counted, identified and removed to avoid competition with new seedlings (Thompson et al. 1997) once per week. Species identification of some species was only possible during flowering (e.g., Pott and Pott 1994, 2000). Vouchers of all species were incorporated in the Herbarium CGMS, at the Universidade Federal de Mato Grosso do Sul. Nomenclature follows APG IV-Angiosperm Phylogeny Group (2016). Species germinated from the seed bank were classified

of the Miranda River, arrows showing the sampled seasonal periods (dry and wet), between the years 2005 and 2015, c representation of the transects following the topographic levels (low, mid and high) in each sampled pond, with five random samples

according to their life cycle (perennial or annual), growth form (aquatic, terrestrial and amphibious) and whether they germinate and establish in a dry or flood environment (Pott and Pott 1994; Leck and Brock 2000; Pott and Pott 2000).

Statistical analysis

First, we constructed species accumulation curves to evaluate seed bank sampling in two treatments: flood and post-flood, and in the wet and dry seasons. Species richness and abundance data fit a Poisson distribution. Generalized linear models (GLMs) (Cai et al. 2012) were used to test the effect of seasonality (wet and dry) and treatment (flood and post-flood) on species 
richness and abundance, as well as the interaction of treatments and seasonality. The influence of these factors on the germination of different life-history strategies and growth forms was analyzed separately for each seasonal period. We conducted a GLM for the species that emerged in the two treatments (flood and post-flood) and in the two periods (wet and dry seasons). All analyses were conducted in R environment (R Core Team 2017), with vegan (Oksanen et al. 2017), permute (Simpson 2016), lattice (Deepayan 2008) and BiodiversityR (Kindt and Coe 2005).

\section{Results}

Richness and abundance of the plant community in the seed bank

The seed bank was composed of a total of 70 species, representing 21 families and 49 genera. A full list of species and authorities is given as Table $\mathrm{S} 1$ in the supplementary material attached to the online version of this paper. Sixteen species were exclusive to the wet season, and one species was exclusive to the dry season. Species richness during the wet season was 66 species, which was greater than during the dry season (51 species) $(z$ ratio $=4.569, p<0.001$, Fig. $2 \mathrm{a})$. Poaceae and Cyperaceae had the highest number of species (11 species each), followed by Plantaginaceae (seven species), Euphorbiaceae (6), and Alismataceae and Asteraceae (five species each). Seedling abundance was almost double in the wet season $(23,134$ seeds compared to the dry season (13,514 seeds) $(z$ ratio $=1.0489, p<0.001$, Fig. $2 b)$.

The species exclusive to the flood treatment were essentially aquatic plants, with the highest abundances of Sagittaria guayanensis (1703 seedlings), Limnocharis flava (1479 seedlings) and Hydrocleys parviflora (1292 seedlings). However, Isoetes pedersenii (a small fern-ally) was also found in the seed bank, with an abundance of 1247 germinated spores limited to the flood treatment (Table S1).

The species accumulation curves suggest that most species in the community were sampled (Fig. S1).

Effect of flood and post-flood on germination of perennial and annual species in the seed bank

In the flood treatment, 32 perennial and six annual species germinated. In the wet season, the number of annual and perennial species in the seed bank was similar $(z$ ratio $=2.270, p=0.581$, Fig. 3a), whereas in the dry season, a significant difference occurred between annual and perennial species ( $z$ ratio $=2.661, p<0.001$, Fig. $3 b$ ). In the postflood treatment, the number of annual species (25 species) increased in relation to flood, but the number of perennials (32) was similar between flood and postflood treatments. Ultimately, there was no difference in the number of annual and perennial species in the post-flood treatment for both sampling seasons.

Similar abundances of annual and perennial species occurred in the wet versus dry season $(z$ ratio $=0.574$, $p=0.581 ; z$ ratio $=0.436, p=0.675$, respectively,
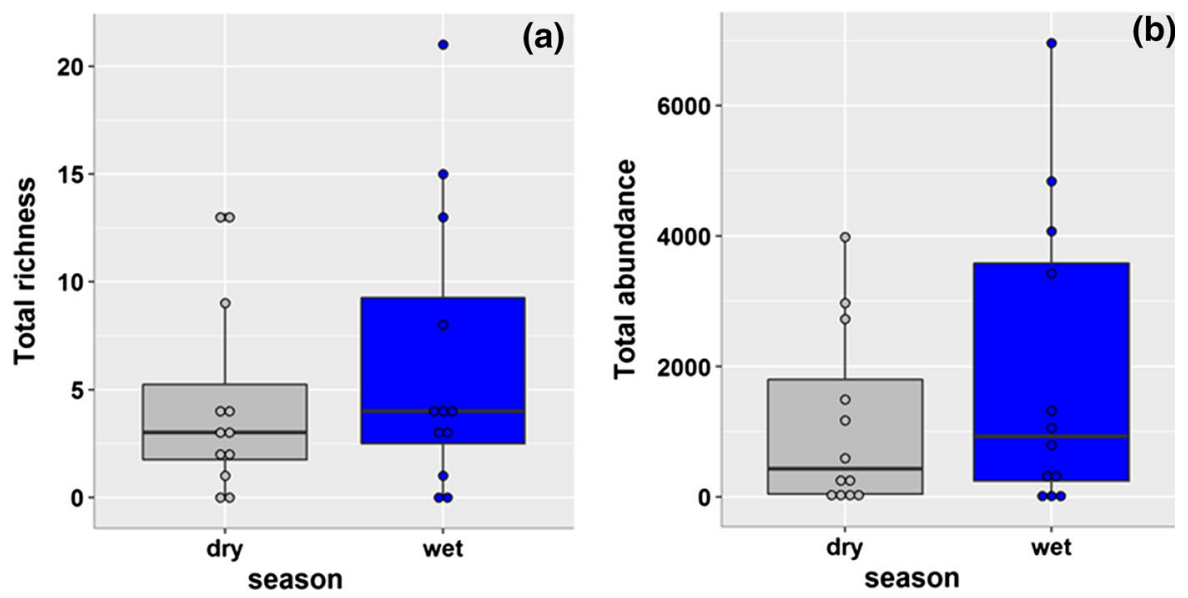

Fig. 2 a Species richness and $\mathbf{b}$ abundance of seeds present in the seasonally flooded grassland seed bank in the Pantanal wetland (Central-West Brazil) 
Fig. 3 Germination of annual and perennial species. Mean richness of germinated seeds $\mathbf{a}$ in the wet and $\mathbf{b}$ dry seasons. Mean abundance of germinated seeds, $\mathbf{c}$ in the wet and $\mathbf{d}$ dry seasons, between the treatments of flood and postflood, from seed bank of seasonally flooded grasslands in the Pantanal wetland (Central-West Brazil)
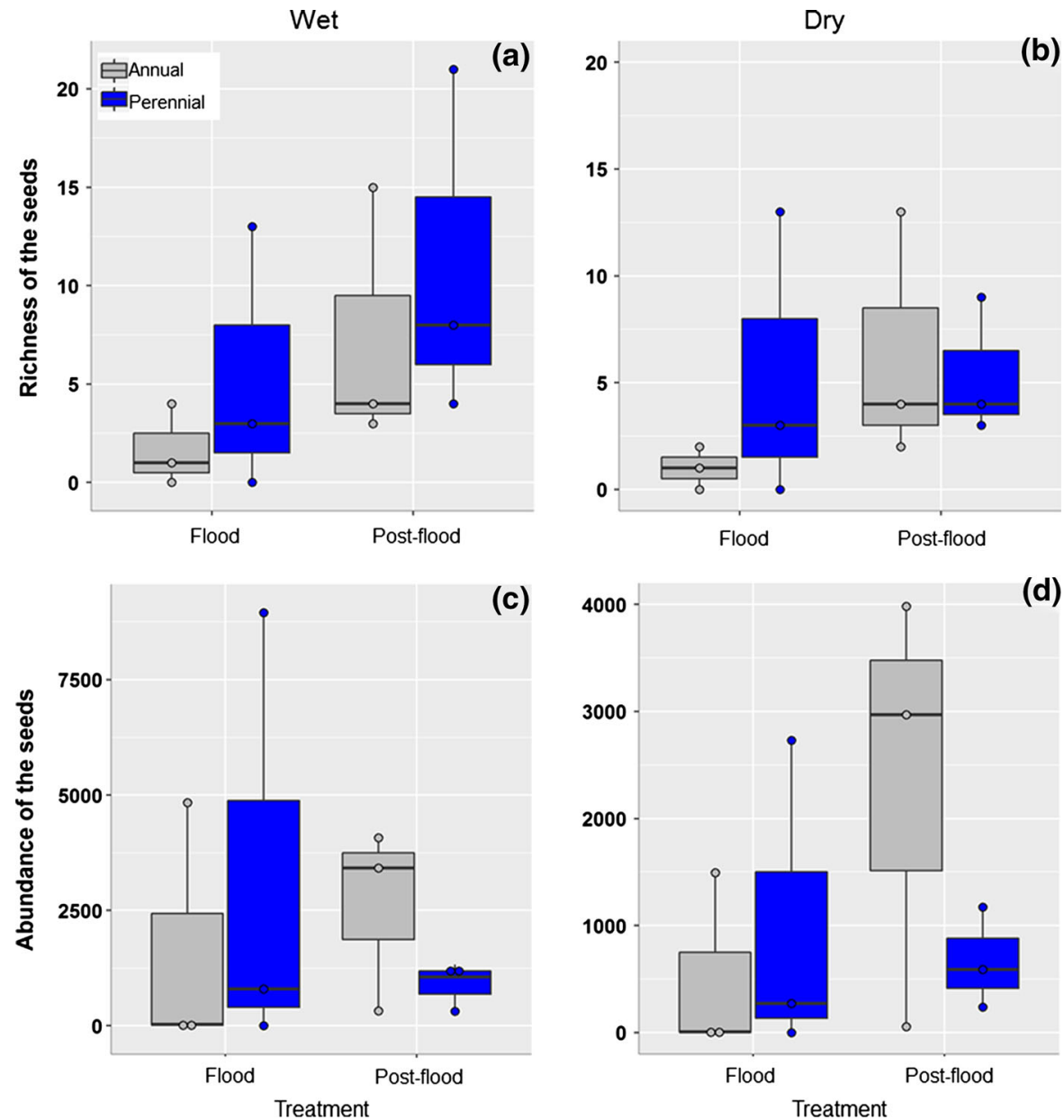

(b)

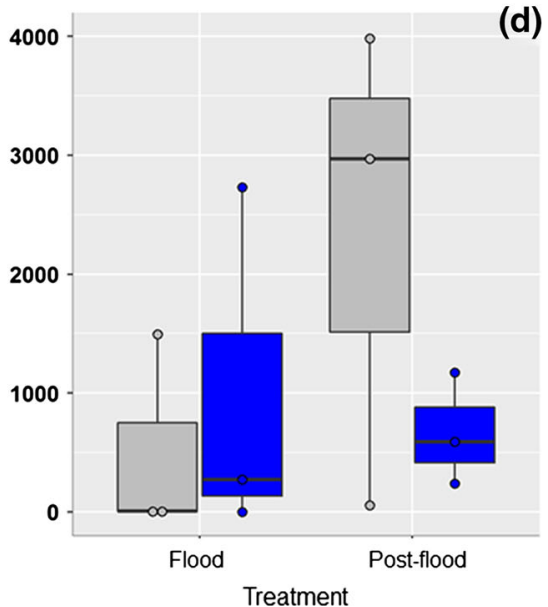

Fig. 3c, d); however, in both the wet and dry seasons, the abundance of annual species was greater than perennial species in the post-flood treatment (wet season: 4378 annuals and 1654 perennials, $z$ ratio $=0.436, p<0.001$, and dry season: 4582 annuals and 1769 perennials, $z$ ratio $=1.417$, $p<0.001$, Fig. 3c, d).

Interaction of seasonal collection and germination environment on growth forms

Seasonality (wet vs. dry) and germination environment (flood and post-flood) interacted to affect the richness and abundance of different growth forms. Species richness of aquatic macrophytes increased in flooded conditions, in both wet and dry sampling seasons (Table S1; wet: $z$ ratio $=1.497, p<0.001$, and dry season $(z$ ratio $=1.976, p<0.001$, Fig. $4 a$, $b)$. The abundance of aquatic macrophytes was three times greater in the wet season (8534 seedlings) than in the dry season (2326 seedlings) with the greatest abundance in the flood treatment across sampling periods (wet: $z$ ratio $=1.976, p<0.001$, dry: $z$ ratio $=0.393, p<0.001$, Fig. $4 c, d)$. Terrestrial plant species only germinated in the post-flood treatment, with a richness of 38 species in the wet season and 23 in the dry season. Abundance of terrestrial species was similar in the wet and dry seasons. Richness of amphibious plants did not differ between seasonal collections or germination treatment (Fig. 4c, d; Table S1); however, there was a greater abundance of amphibious species that germinated from samples collected in the wet season than in the dry.

Yet, in the dry season seed germination of amphibious species was three times higher in the post-flood treatment than in the flood treatment $(z$ ratio $=7.872, p<0.001$, Fig. $4 d)$. Four species 
Fig. 4 Effect of treatments of flood and post-flood on species richness $\mathbf{a}$ in the wet and $\mathbf{b}$ dry seasons; and on seed abundance, $\mathbf{c}$ in the wet and $\mathbf{d}$ dry seasons, between the different growth forms, in seasonally flooded grasslands in the Pantanal wetland (Central-West Brazil)
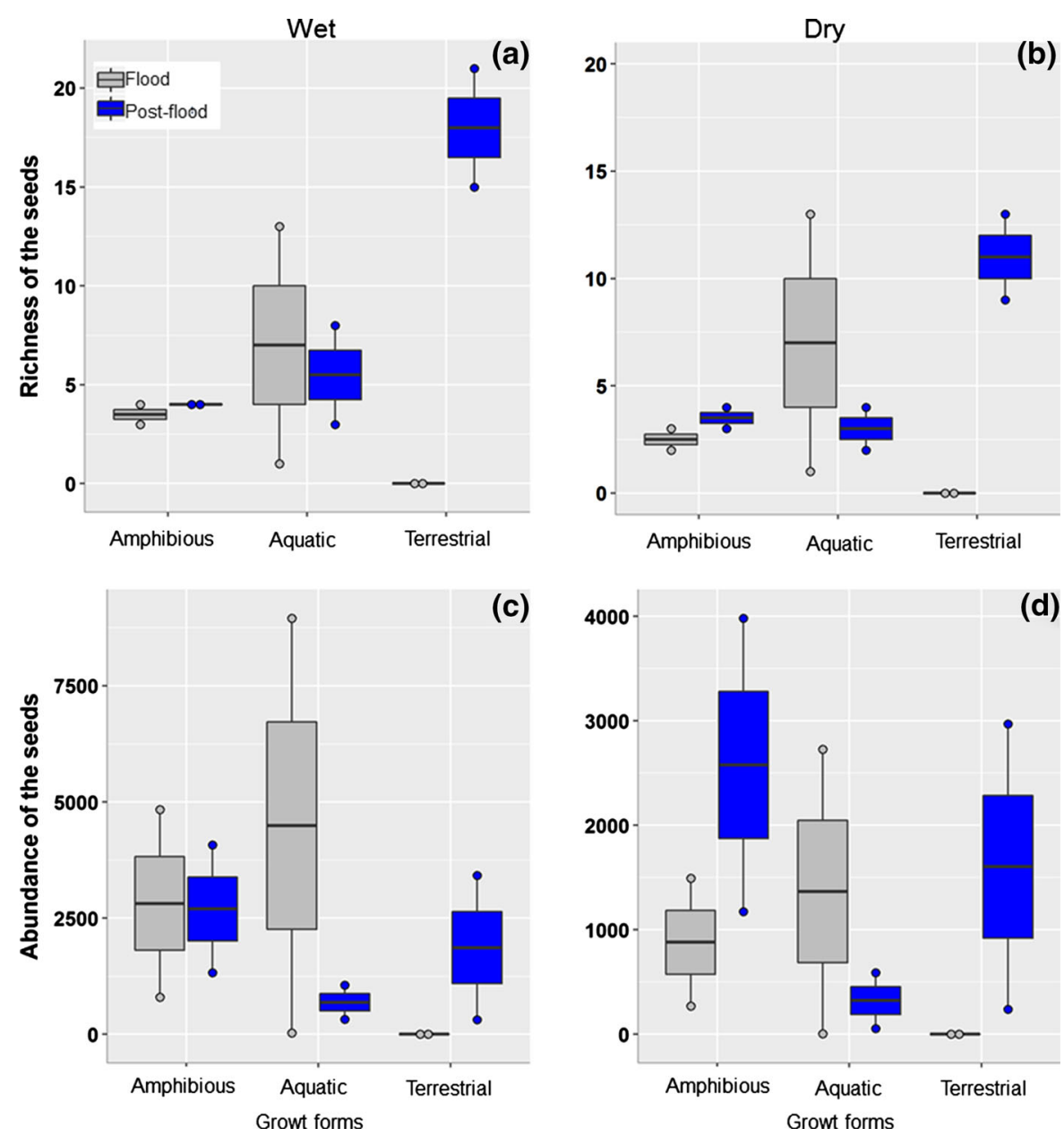

(b)
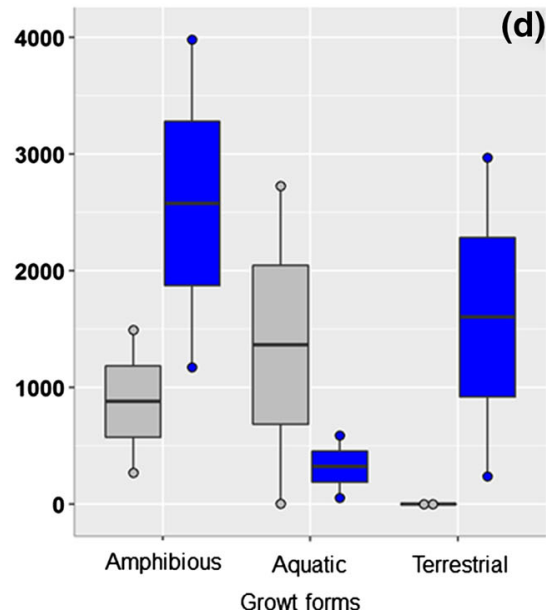

occurred in all treatments and in all sampling seasons and had the greatest abundance of germinated seeds: Rotala ramosior (8989 seedlings), Eleocharis minima (3826), Bacopa australis (3581) and Helanthium tenellum (1564) (Table 1).

In the individual analysis of each species, $R$. ramosior had similar germination in flood versus post-flood conditions; however, germination of the other species differed between treatments (Fig. 5). Only E. minima had higher germination in the postflood treatment (Table 1). Yet, these species had higher germination from soil in the wet season than in the dry season: $R$. ramosior $(z$ ratio $=5.774$, $p<0.001$, Fig. 5a), B. australis ( $z$ ratio $=11.738$, $p<0.001$, Fig. 5b), E. minima $(z$ ratio $=5.544$,

Table 1 Number of emerged seedlings in the treatments flood and post-flood of four species shared between two seasonal periods (dry and wet), from the soil seed bank of seasonally flooded grassland in the Pantanal wetland (Central-West Brazil)

\begin{tabular}{lccccccc}
\hline Species & Flood & Post-flood & Estimate & Mean & SE & $\operatorname{Pr}(>|t|)$ & $t$ value \\
\hline Rotala ramosior & 4854 & 4135 & 0.1603 & 1.8516 & 0.0907 & 0.0777 & 1.7666 \\
Bacopa australis & 2350 & 1231 & 0.6466 & 1.2495 & 0.1107 & 0.0044 & 2.849 \\
Helanthium tenellum & 914 & 650 & 0.3408 & 1.2512 & 0.1316 & 0.0097 & 2.590 \\
Eleocharis minima & 1631 & 2195 & 0.2970 & 1.8986 & 0.1021 & 0.0037 & 2.910 \\
\hline
\end{tabular}


Fig. 5 Total abundance of emerged seedlings of four shared species under the treatments flood and postflood: a Rotala ramosior, b Bacopa australis, c Eleocharis minima and d Helanthium tenellum, from the soil seed bank of two seasonal periods (wet and dry) of floodable grasslands in the Pantanal wetland (Central-West Brazil)
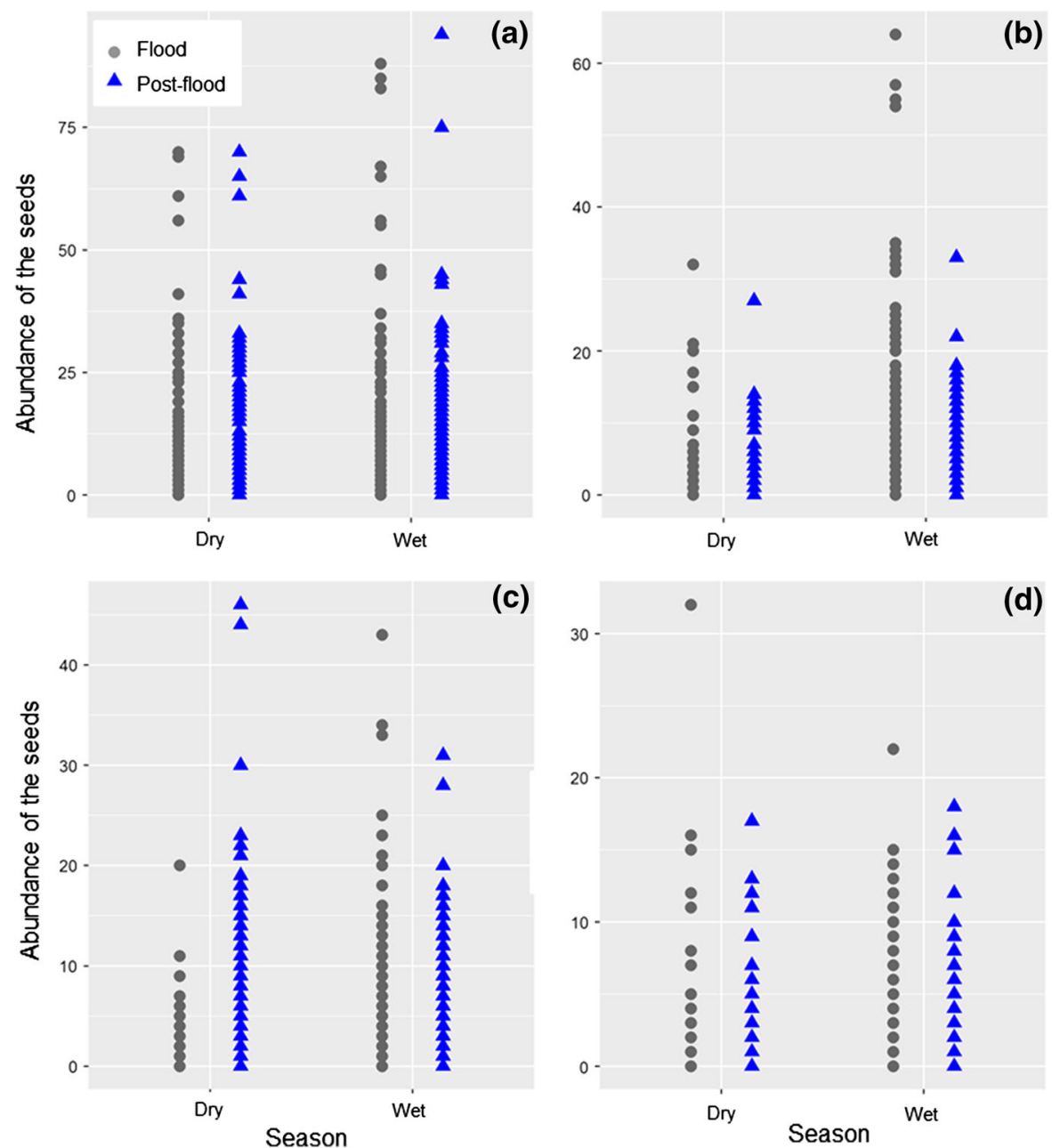

$p<0.001$, Fig. 5c) and H. tenellum $(z$ ratio $=6.292$, $p<0.001$, Fig. 5d).

\section{Discussion}

Regeneration of seasonally flooded grasslands, such as those of the Pantanal, occurs through the high regeneration capacity of annual and perennial species (Zobel et al. 1998), which have distinct germination strategies, varying according to the environmental conditions (Liu et al. 2009), and the abundance of annual species in the seed bank (Bao et al. 2014; Souza et al. 2016). In our study, three strategies/traits of germination were found in the seed bank of floodable grasslands in the Pantanal, according to soil flooding and drought.
Richness and abundance of the plant community in the seed bank

The abundance and richness of the seed bank varied between the treatments of flood and post-flood. The treatment with soil inundation revealed a seed bank full of aquatic macrophytes (Fig. 2S). Nevertheless, similar to other reports (van der Valk and Davis 1978; Leck and Simpson 1987; Boedeltje et al. 2002), there was a higher species richness and abundance of seedlings from non-inundated soil than submerged soil. In spite of the low species richness in flood conditions, perennial species were very abundant. Initially, emergence of Rotala ramosior and Bacopa australis was high followed by mostly aquatic species such as Hydrocleys parviflora, Limnocharis flava and Sagittaria guayanensis, and plants commonly found in 
temporary ponds, such as Pontederia parviflora, Echinodorus grandiflorus and Helanthium tenellum (Pott and Pott 2004).

High species richness of Poaceae and Cyperaceae is characteristic of seasonal savannas, where aquatic and terrestrial phases alternate, with predominance of the grasses Reimarochloa spp., Axonopus purpusii, Paspalum spp. (Pott and Pott 1997, 2004). In the seed bank, we also found Digitaria bicornis, D. fuscescens and Setaria parviflora in high abundance. Under increased moisture, the grassland is filled with Cyperus spp. and Eleocharis spp. (Pott and Pott 2004). All recorded species are present in the list of flora of the Pantanal (Pott and Pott 1999).

The high occurrence of spores of Isoetes perdersenii in the seed bank was also reported in flooded grasslands in the northern Pantanal (Oliveira et al. 2015), where it represented over $50 \%$ of the diaspores present in the soil. The presence of spores in the soil in both seasons is in contrast to a previous report by Bao et al. (2015), who observed the occurrence of this fernally species only in the wet season. Based on our observations of spores in both seasons, we hypothesize that this species may form a persistent bank of propagules.

The species accumulation curves illustrated the importance of sampling wetlands in two seasonal periods (wet and dry) and evaluating the seed bank under both flood and post-flood conditions to maximize the representation of seeds and seedling emergence strategies. Seasonal and flooded and drained germination conditions can improve estimates of richness of the vegetation (e.g., van der Valk and Davis 1978, 1979; Bonis et al. 1995; Smolders et al. 1995; Brock 1997, 2011; Boedeltje et al. 2002; Price et al. 2010), in addition to reflecting the ecologically active species present in the seed bank (Haag 1983), particularly for species producing dormant seeds (van der Valk and Davis 1978; Bonis et al. 1995). This bias can make a considerable difference, since, in our study, the germination rate under experimental flood conditions increased the species abundance and richness of the plant community. Without the flood conditions, aquatic species would have been neglected. This information has enhanced our understanding of seed banks in these flooded grasslands, as previous studies of the seed bank in the Pantanal did not evaluate the flood conditions (e.g., Pagotto et al. 2011; Bao et al. 2014).
Effect of flood and post-flood conditions on germination of perennial and annual species in the seed bank

Greater richness of perennial species in the seed bank in flooded conditions reveals that many species of temporarily wet zones form seed banks, rich in perennial species (Fig. 2S). It is known that the seed bank of perennials is in general persistent (Thompson and Grime 1979), due to the dormancy of most species of this group. However, the germination strategies of many species are limited by environmental conditions (Saatkamp et al. 2014), and some species may change their strategies according to environmental variation. Yet, the low richness of annual plants in relation to perennials, compared with other wetlands (e.g., Skoglund and Hytteborn 1990; Leck and Brock 2000), can be due to our experimental conditions that favored the germination of many aquatic plants and perennials. The knowledge of the seeds that make up the bank and that are potentially able to regenerate these pasture fields during and after the extreme seasonal event.

In wetlands, where the environment is variable, reproduction can fail in some consecutive years, which makes seed banks critical for the persistence of the plant community (Bonis et al. 1995), providing a mechanism to buffer the effect of seasonal events impacting the capacity of the seed bank to regenerate these plant communities. Our data reveal that many perennial species present in the seed bank are able to colonize during and after flood disturbances, supplementing the mechanisms of regrowth and vegetative propagation otherwise characteristic of grasses and sedges (Ernst et al. 1992), characteristic of grasses and sedges.

The communities of annual and perennial plants in a variable environment undergo strong variations of abundance over time (Venable and Lawlor 1980). The variation in density of seeds in the soil depends mainly on germination and reproduction of each species (Bonis et al. 1995). In our study, the abundance of annual over perennial species, in post-flood (Fig. 3S), was due to annual species producing large quantities of seeds (Oliveira et al. 2015; Souza et al. 2016), which disperse readily (Cohen 1967; Bonis et al. 1995; Baldwin and Derico 1999). Nonetheless, it is evident that after a flood, there is an increase in emergence of annuals (Souza et al. 2016). 
A higher number of seeds retained in the soil corresponding to a flood period is characteristic of seasonally flooded wetlands (e.g., in the Pantanal: Pagotto et al. 2011; Bao et al. 2014; Oliveira et al. 2015; Souza et al. 2016; in others wetlands: Bertiller 1992, Leck and Leck 1998; Leck and Brock 2000; Brock 2011), due to the increased incidence of dispersal corridors (Johansson et al. 1996; Middleton 2003), and seeds being trapped in areas of lower elevation (Pagotto et al. 2011; Bao et al. 2014).

Interaction of seasonal collection and germination environment on growth forms

The coexistence of aquatic, amphibious and terrestrial plants in wetlands indicates that these grasslands are large amphibious habitats under constant succession (Pott et al. 2011). Species replacement is caused by the environmental conditions required by different growth forms for germination and growth, related to seasonal conditions of moisture, temperature and flooding in each season (Grillas et al. 1991).

We observed an interaction between growth forms and germination treatments of flood and post-flood due to the groups of aquatic and terrestrial plants having their germination restricted by the presence or absence of a flood. Some essentially aquatic species occasionally germinated following inundation, although no terrestrial species germinated while flooded.

In these seasonally flooded savannas, the predominance of terrestrial grasses was high, but as flooding begins, numerous other terrestrial, amphibious and aquatic herbs cover the ground, followed by previously dormant aquatic macrophytes (Pott et al. 2011). As the water recedes, the aquatic species die and form a layer of organic debris (Bonis et al. 1995) and terrestrial annual herbaceous species germinate (Bonis and Lepart 1994; Bonis et al. 1995). Thus, the similarity of the seed bank is high before and after flood (Bao et al. 2014), reflecting the seasonal dynamics of these plant communities (Casanova and Brock 1990) and the capacity to reestablish during and after an extreme seasonal flooding event (Bao et al. 2015).

Our results reveal that many aquatic plants species have high potential to colonize wetlands via the seed bank, contrary to the findings of other studies that reported colonization of such plants only when vegetative propagules such as rhizomes or bulbs are present in the soil (Brix 1994; Poschlod et al. 1999; Engelhardt and Ritchie 2001; Sosnová et al. 2010). The germination rate is related to the level of variability of the environment and to the number of seeds present in the soil (Venable and Lawlor 1980).

For the group of amphibious plants, we did not observe differences between the treatments and between seasons. The coexistence of amphibious and terrestrial plants is high, as well as of the amphibious and aquatic plants. However, for aquatic and terrestrial plants there was no interaction. Germination of these groups fluctuates strongly with environmental conditions (Baskin and Baskin 2014), which allows the exclusion of species or of a group, according to the flood level (Van der Valk 1981). The seed bank introduces an effect of storage of seeds capable to colonize, either in years of flood or prolonged drought.

The seed bank seems to be formed by groups of seeds that can go extinct for a time and/or remain in the grassland constantly, independent of environmental conditions. Considering the latter, we found, our bank revealed four species with high germination rates: $R$. ramosior, B. australis, $H$. tenellum and E. minima (Fig. 3S). These small herbaceous species are consistently found in the seed banks in the Pantanal (Pagotto et al. 2011; Bao et al. 2014; Oliveira et al. 2015; Sousa et al. 2016), and in natural grasslands comma and grow intermingled with native and exotic grasses (Bao et al. 2015). They represent a group of "flexible" species that germinate and become established in the field, independent of flood/dry dynamics.

\section{Conclusions and future perspectives}

This study highlights three germination strategies of species represented in the seed bank of floodable grasslands in the present study: (I) annual and perennial species of aquatic and some amphibious plants when the soil is under total inundation-(II) an explosion of annual species, with amphibious and terrestrial plants, immediately after the flood during drawdown, and (III) some annual species and numerous perennial grasses and sedges, typically terrestrial, which start germination post-flood. When the soil is flooded, most annual and some perennial grasses are excluded and conversely; when soil is no longer flooded, aquatic plants (mostly perennialsmany Cyperaceae) are largely excluded. Nonetheless, 
Flood

(I)
Post-flood

(II)
(III)

Perennial grasses and sedges

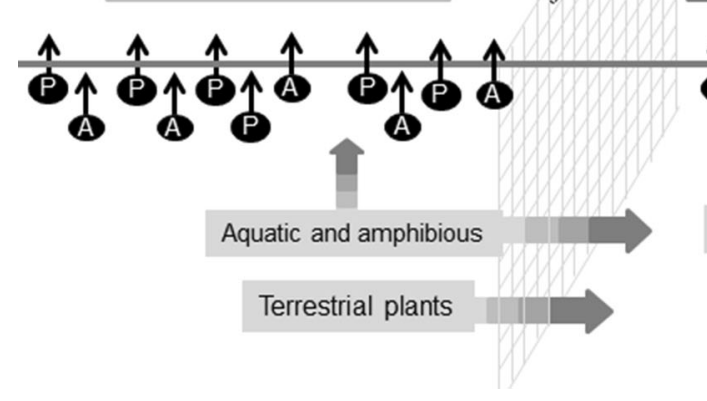

Fig. 6 General scheme of three germination strategies in our experimental study on the bank of seeds of seasonally flooded grassland: (I) when the soil is under full flood; (II) when the soil

some species adapted to these seasonal systems can germinate and become established under either conditions (Fig. 6).

The dynamics of flood and dry conditions in these seasonal grasslands are important, with each group of species having its germination strategy, according to the environmental conditions. Our results show that this plant community has high species richness and abundances of seeds, which contributes to the initial colonization during and after seasonal events. Climate change, leading to reduced flooding, may modify this scenario, where large groups of species may be lost if flooding declines or increases over time. In our study over 2 years of sampling, it was not possible to verify a temporal change in the composition of the vegetation. But it is worth noting the importance of the evaluation of the seed bank as the main source of maintenance of the plant community, mainly because it contains species of different growth forms. We also highlight the importance of evaluating seed banks in different seasons and in two phases: flood and dry, to better assess the plant diversity of seasonally flooded grasslands. is immediately released from the flood; and (III) over the months maintaining the soil moisture

\section{References}

Allem AC, Valls JFM (1987) Recursos forrageiros nativos do Pantanal Mato-grossense. EMBRAPA-CENARGEN, Brasília, Documentos 8

Ames GM, Anderson SM, Wright JP (2015) Multiple environmental drivers structure plant traits at the community level in a pyrogenic ecosystem. Funct Ecol 30:789-798. https:// doi.org/10.1111/1365-2435.12536

Apg IV (2016) An update of the angiosperm phylogeny group classification for the orders and families of flowering plants: APG IV. Bot J Linean Soc 181:1-20. https://doi. org/10.1111/boj.12385

Baldwin AH, Derico E (1999) The seed bank of a restored tidal freshwater marsh in Washington, DC. Urban Ecosyst 3:5-20. https://doi.org/10.1023/A:1009549117419

Bao F, Pott A, Ferreira FA, Arruda R (2014) Soil seed bank of floodable native and cultivated grassland in the Pantanal wetland: effects of flood gradient, season and species invasion. Braz J Bot 37:239-250. https://doi.org/10.1007/ s40415-014-0076-Z

Bao F, Assis MA, Arruda R, Pott A (2015) Effects of Urochloa humidicola on plant diversity in native grasslands in a Neotropical wetland. Wetlands 35:841-850. https://doi. org/10.1007/s13157-015-0673-z

Barton ML, Medel ID, Johnston KK, Whitcraft CR (2016) Seed collection and germination strategies for common wetland and costal sage scrub species in southern California. BioOne 115:41-71. https://doi.org/10.3160/soca-115-0141-71.1

Baskin C, Baskin J (2014) Seeds: ecology, biogeography, and evolution of dormancy and germination, 2nd edn. Academic Press, London 
Bertiller MB (1992) Seasonal variation in the seed bank of a Patagonian grassland in relation to grazing and topography. J Veg Sci 3:47-54. https://doi.org/10.2307/3235997

Boedeltje G, Heerdt GNJ, Bakker JP (2002) Applying the seedling-emergence method under waterlogged conditions to detect the seed bank of aquatic plants in submerged sediments. Aquat Bot 72:121-128. https://doi.org/10.1016/ S0304-3770(01)00224-8

Bonis A, Lepart J (1994) Vertical structure of seed banks and the impact of depth of burial on recruitment in two temporary marshes. Vegetatio 112:127-139. https://doi.org/10.1007/ BF00044687

Bonis A, Lepart J, Grillas P (1995) Seed bank dynamics and coexistence of annual macrophytes in temporary and variable habitat. Oikos 74:81-92. https://doi.org/10.2307/ 3545677

Brix H (1994) Functions of macrophytes in constructed wetlands. Water Sci Technol 29:71-78

Brock MA (1997) Are there seeds in your wetlands?. Land \& Water Resources: Research \& Development Corporation, University of New England, Armidale

Brock MA (2011) Persistence of seed banks in Australian temporary wetlands. Freshwater Biol 56:1312-1327. https://doi.org/10.1111/j.1365-2427.2010.02570.x

Cai C, Zou Y, Peng Y, Zhang J (2012) Smcure: an R-package for estimating semiparametric mixture cure models. Comput Meth Prog Biomed 108:1255-1260

Casanova MT, Brock MA (1990) Charophytes germination and establishment from the seed bank of an Australian temporary lake. Aquat Bot 36:247-254. https://doi.org/10. 1016/0304-3770(90)90038-M

Cohen D (1967) Optimizing reproduction in a randomly varying environment when a correlation may exist between the conditions at the time a choice has to be made and the subsequent outcome. J Theor Biol 16:1-14. https://doi.org/ 10.1016/0022-5193(67)90050-1

Dalling JW, Swaine MD, Garwood NC (1998) Dispersal patterns and seed bank dynamics of pioneer trees in moist tropical forest. Ecology 79:564-578. https://doi.org/10. 1890/0012-9658(1998)079[0564:DPASBD]2.0.CO;2

Deepayan S (2008) Lattice: multivariate data visualization with R. Springer, New York. URL ISBN 978-0-387-75968-5

Engelhardt KAM, Ritchie ME (2001) Effects of macrophyte species richness on wetland ecosystem functioning and services. Nature 411:687-689. https://doi.org/10.1038/ 35079573

Ernst WHO, Veenendaal EM, Kebakile MM (1992) Possibilities for dispersal in annual and perennial grasses in a Savanna in Botswana. Vegetatio 102:1-11. https://doi.org/10.1007/ BF00031700

Grillas P, Van Wijck C, Bonis A (1991) Life history traits: a possible cause for the higher frequency of occurrence of Zannichellia pedunculata than Zannichellia obtusifolia in temporary marshes. Aquat Bot 42:1-13. https://doi.org/10. 1016/0304-3770(91)90101-A

Grime JP (1977) Evidence for the existence of three primary strategies in plants and its relevance to ecological and evolutionary theory. Am Nat 111:1169-1194. https://doi. org/10.1086/283244
Haag RW (1983) Emergence of seedlings of aquatic macrophytes from lake sediments. Can J Bot 61:148-156. https:// doi.org/10.1139/b83-014

Hölzel N, Otte A (2001) The impact of flooding regime on the soil seed bank of flood-meadows. J Veg Sci 12:209-218. https://doi.org/10.2307/3236605

Hubbell SP, Foster RB (1986) Biology, chance, and history and the structure of tropical rain forest tree communities. In: Diamond J, Case TJ (eds) Community ecology. Harper \& Row, New York, pp 314-329

Johansson ME, Nilsson C, Nilsson E (1996) Do rivers function as corridors for plant dispersal? J Veg Sci 7:593-598. https://doi.org/10.2307/3236309

Junk WJ (1993) Wetlands of tropical South America. In: Whigham DF, Dyrygova D, Hejny S (eds) Wetlands of the world, inventory and management. Kluwer, Dordrecht, pp 679-739

Jutila HM (2001) Effect of flooding and draw-down disturbance on germination from a seashore meadow seed bank. J Veg Sci 12:729-738. https://doi.org/10.2307/3236914

Kindt R, Coe R (2005) Tree diversity analysis. A manual and software for common statistical methods for ecological and biodiversity studies. World Agroforestry Centre (ICRAF), Nairobi. URL ISBN 92-9059-179-X

LaDeua SL, Ellison AM (1999) Seed bank composition of a northeastern U.S. Tussock. Wetlands 19:255-261. https:// doi.org/10.1007/BF03161755

Leck MA, Brock MA (2000) Ecological and evolutionary trends in wetlands: evidence from seeds and seed banks in New South Wales, Australia and New Jersey, USA. Plant Species Biol 15:97-112. https://doi.org/10.1046/j.1442-1984. 2000.00031.x

Leck MA, Leck CF (1998) A ten-year seed bank study of old field succession in central New Jersey. J Torrey Bot Soc 125:11-32. https://doi.org/10.2307/2997228

Leck MA, Simpson RL (1987) Seed bank of a freshwater tidal wetland: turnover and relationship to vegetation change. Am J Bot 74:360-370

LePage PT, Caham CD, Coates KD, Bartemucci P (2000) Seed abundance versus substrate limitation of seedling recruitment in northern temperate forest of British Colombia. Can J For Res 30:415-427. https://doi.org/10.1139/x99-223

Liu W, Zhang Q, Liu G (2009) Seed banks of a river-reservoir wetland system and their implications for vegetation development. Aquat Bot 90:7-12. https://doi.org/10.1016/ j.aquabot.2008.04.014

Long RL, Gorecki MJ, Renton M, Scott JK, Colville L, Goggin DE, Commander LE, Westcott DA, Cherry H, FinchSavage WE (2015) The ecophysiology of seed persistence: a mechanistic view of the journey to germination or demise. Biol Rev 90:31-59. https://doi.org/10.1111/brv. 12095

Middleton BA (2003) Soil seed banks and the potential restoration of forested wetland after farming. J Appl Ecol 40:1025-1034. https://doi.org/10.1111/j.1365-2664.2003. 00866.x

Muller-Landau HC, Wright J, Calderón O, Hubbell SP, Foster RB (2002) Assessing recruitment limitation: concepts, methods and case-studies from a tropical forest. Seed dispersal and frugivory: ecology, evolution and conservation. CAB International, Wallingford, pp 35-53 
Nielsen DL, Hillman TJ, Smith FJ, Shiel RJ (2002) The influence of seasonality and duration of flooding on zooplankton in experimental billabongs. River Res Appl 18:227-237

Oksanen J, Blanchet GF, Friendly M, Kindt R, Legendre P, McGlinn D, Minchin PR, O'Hara RB, Simpson GL, Solymos P, Stevens MHH, Szoecs E, Wagner H (2017) Vegan: community ecology package. $\mathrm{R}$ package version 2.4-3. URL CRAN.R-project.org/package = vegan

Oliveira PC, Torezan JM, Nunes da Cunha C (2015) Effects of flooding on the spatial distribution of soil seed and spore banks of native grasslands of the Pantanal wetland. Acta Bot Bras 29:400-407. https://doi.org/10.1590/0102$33062015 \mathrm{abb} 0027$

Pagotto MA, Silveira RML, Nunes da Cunha C, Fantin-Cruz I (2011) Distribution of herbaceous species in the soil seed bank of a flood seasonality area, Northern Pantanal, Brazil. Int Rev Hydrobiol 96:149-163. https://doi.org/10.1002/ iroh.201111315

Poschlod P, Böhringer J, Fennel S, Prume C, Tiekötter A (1999) Aspekte der biologie und ökologie von Arten der Zwergbinsenfluren. Mitt bad Landesver Naturkunde u Naturschutz NF 17:219-260

Pott A, Pott VJ (1994) Plantas do Pantanal. Empresa Brasileira de Pesquisa Agropecuária, Brasília

Pott VJ, Pott A (1997) Checklist das macrófitas aquáticas do Pantanal, Brasil. Acta Bot Bras 11:215-227. https://doi. org/10.1590/S0102-33061997000200010

Pott A, Pott VJ (1999) Flora do Pantanal-listagem atual de fanerógamas. In: Anais do simpósio sobre recursos naturais e sócio-econômicos do Pantanal, Manejo e Conservação, 2rd edn. Embrapa Pantanal, Corumbá, pp 297-325

Pott VJ, Pott A (2000) Plantas aquáticas do Pantanal. Embrapa: Centro de Pesquisa Agropecuária do Pantanal, Brasília

Pott A, Pott VJ (2004) Features and conservation of the Brazilian Pantanal wetland. Wetlands Ecol Manag 12:522-547. https://doi.org/10.1007/s11273-005-1754-1

Pott A, Silva JSV (2015) Terrestrial and aquatic vegetation diversity of the Pantanal Wetland. In: Bergier I, Assine ML (eds) Dynamics of the Pantanal Wetland in South America. Springer, Cham, pp 111-151

Pott VJ, Pott A, Lima LCP, Moreira SN, Oliveira AKM (2011) Aquatic macrophyte diversity of the Brazilian Pantanal wetland and upper basin. Braz J Biol 71:255-263

Price JN, Wright BR, Gross CL, Whalley WRDB (2010) Comparison of seedling emergence and seed extraction techniques for estimating the composition of soil seed banks. Method Ecol Evol 1:151-157. https://doi.org/10. 1111/j.2041-210X.2010.00011.x

R Core Team (2017) R: a language and environment for statistical computing. R Foundation for Statistical Computing, Vienna, Austria. URL https://www.R-project.org/
Saatkamp A, Poschlod P, Venable DL (2014) The functional role of soil seed banks in natural communities. In: Gallagher RS (ed) Seeds: the ecology of regeneration in plant communities, 3rd edn. C.A.B. International, Wallingford, pp 263-295

Schneider R (1994) The role of hydrologic regime in maintaining rare plant communities of New York's coastal plain pondshores. Biol Conserv 68:253-260. https://doi.org/10. 1016/0006-3207(94)90413-8

Silva JSV, Abdon MM (1998) Delimitação do Pantanal brasileiro e suas sub regiões. Pesq Agrop Bras 33:1703-1711

Simpson GL (2016) permute: functions for generating restricted permutations of data. $\mathrm{R}$ package version 0.9-4. URL CRAN.R-project.org/package $=$ permute

Skoglund J, Hytteborn H (1990) Viable seeds in deposits of the former lakes Kvismaren and Hornborgasjon, Sweden. Aquat Bot 37:271-290

Smolders AJP, Den Hartog C, Roelofs JGM (1995) Germination and seedling development in Stratiotes aloides L. Aquat Bot 51:269-279. https://doi.org/10.1016/03043770(95)00462-9

Sosnová M, van Diggelen R, Klimesová J (2010) Distribution of clonal growth forms in wetlands. Aquat Bot 1:33-39. https://doi.org/10.1016/j.aquabot.2009.09.005

Souza EB, Ferreira FA, Pott A (2016) Effects of flooding and its temporal variation on seedling recruitment from the soil seed bank of a Neotropical floodplain. Acta Bot Bras 31:64-75. https://doi.org/10.1590/0102-33062016abb0 202

Thompson K, Grime JP (1979) Seasonal variation in the seed banks of herbaceous species in ten contrasting habitats. J Ecol 67:893-921. https://doi.org/10.2307/2259220

Thompson K, Bakker JP, Bekker RM (1997) The soil seed banks of North West Europe: methodology, density and longevity. Cambridge University Press, Cambridge

van der Valk AG (1981) Succession in wetlands: a Gleosonian approach. Ecology 62:68-696. https://doi.org/10.2307/ 1937737

van der Valk AG, Davis CB (1978) The role of seed banks in the vegetation dynamics of prairie glacial marshes. Ecology 59:322-335. https://doi.org/10.2307/1936377

van der Valk AG, Davis CB (1979) A reconstruction of the recent vegetational history of a prairy marsh Eagle, Lake, Iowa, from its seed bank. Aquat Bot 6:29-51. https://doi. org/10.1016/0304-3770(79)90049-4

Venable DL, Lawlor L (1980) Delayed germination and dispersal in desert annuals: escape in space and time. Oecologia 46:272-282. https://doi.org/10.1007/BF00540137

Zobel M, van der Maarel, Dupré C (1998) Species pool: the concept, its determination and significance for community restoration. Appl Veget Sci 1:55-66. https://doi.org/10. $2307 / 1479085$ 